\title{
Benefits of maltodextrin intake 2 hours before cholecystectomy by laparotomy in respiratory function and functional capacity: a prospective randomized clinical trial
}

\author{
Benefícios na função respiratória e capacidade funcional com ingesta de maltodextrina \\ 2 horas antes de colecistectomia por laparotomia: ensaio clínico prospectivo e randomizado
}

Fabiana Vieira Breijão Zani ${ }^{1}$, José Eduardo Aguilar-Nascimento ${ }^{1}$, Diana Borges Dock Nascimento ${ }^{1}$, Ageo Mário Cândido da Silva ${ }^{1}$, Fernanda Stephan Caporossi ${ }^{1}$, Cervantes Caporossi ${ }^{1}$

\section{ABSTRACT}

Objective: To evaluate the change in respiratory function and functional capacity according to the type of preoperative fasting. Methods: Randomized prospective clinical trial, with 92 female patients undergoing cholecystectomy by laparotomy with conventional or 2 hours shortened fasting. The variables measured were the peak expiratory flow, forced expiratory volume in the first second, forced vital capacity, dominant handgrip strength, and non-dominant handgrip strength. Evaluations were performed 2 hours before induction of anesthesia and 24 hours after the operation. Results: The two groups were similar in preoperative evaluations regarding demographic and clinical characteristics, as well as for all variables. However, postoperatively the group with shortened fasting had higher values than the group with conventional fasting for lung function tests peak expiratory flow $(128.7 \pm 62.5$ versus $115.7 \pm 59.9$; $\mathrm{p}=0.040)$, forced expiratory volume in the first second $(1.5 \pm 0.6$ versus $1.2 \pm 0.5 ; p=0.040)$, forced vital capacity $(2.3 \pm 1.1$ versus $1.8 \pm 0.9 ; p=0.021)$, and for muscle function tests dominant handgrip strength $(24.9 \pm 6.8$ versus $18.4 \pm 7.7 ; p=0.001)$ and non-dominant handgrip strength $(22.9 \pm 6.3$ versus $17.0 \pm 7.8 ; p=0.0002)$. In the intragroup evaluation, there was a decrease in preoperative compared with postoperative values, except for dominant handgrip strength (25.2 \pm 6.7 versus $24.9 \pm 6.8 ; p=0.692)$, in the shortened fasting group. Conclusion: Abbreviation of preoperative fasting time with ingestion of maltodextrin solution is beneficial to pulmonary function and preserves dominant handgrip strength.

Keywords: Fasting; Cholecystectomy; Preoperative care; Spirometry; Muscle strength; Polysaccharides/metabolism

Clinical trial register (www.ensaiosclinicos.gov.br): protocol ID: UTN: U1111-1148-3196

\section{RESUMO}

Objetivo: Avaliar a alteração da função respiratória e da capacidade funcional, conforme o tipo de jejum pré-operatório. Métodos: Ensaio clínico prospectivo randomizado, com 92 pacientes do sexo feminino, submetidas à colecistectomia por laparotomia, observando jejum convencional ou abreviado de 2 horas com maltodextrina. As variáveis foram: pico de fluxo expiratório, volume expiratório no primeiro segundo, capacidade vital forçada, força de preensão palmar dominante e força de preensão palmar não dominante. As avaliações foram realizadas 2 horas antes da indução anestésica e 24 horas após a operação. Resultados: 0 s dois grupos foram semelhantes quanto às características demográficas, clínicas e em todas as variáveis estudadas, quando avaliadas no pré-operatório. No entanto, no pós-operatório, o grupo abreviado apresentou valores maiores que 0 grupo convencional para pico de fluxo expiratório $(128,7 \pm 62,5$ versus $115,7 \pm 59,9 ; p=0,040)$, volume expiratório no primeiro segundo $(1,5 \pm 0,6$ versus $1,2 \pm 0,5$; $p=0,040)$, capacidade vital forçada $(2,3 \pm 1,1$ versus $1,8 \pm 0,9$; $p=0,021)$, força de preensão palmar dominante $(24,9 \pm 6,8$ versus $18,4 \pm 7,7 ; p=0,001)$ e força de preensão palmar não dominante $(22,9 \pm 6,3$ versus $17,0 \pm 7,8 ; p=0,0002)$. Na avaliação intragrupo, houve diminuição nas variáveis ao se compararem os valores do pré-operatório em relação ao pós-operatório, exceto para força de preensão palmar dominante $(25,2 \pm 6,7$ versus $24,9 \pm 6,8 ; p=0,692)$ no grupo de jejum abreviado. Conclusão: $A$ abreviação do tempo de jejum pré-operatório com solução contendo maltodextrina beneficia a função pulmonar e preserva a força de preensão palmar dominante.

Descritores: Jejum; Colecistectomia; Cuidados pré-operatórios; Espirometria; Força muscular; Polissacarídeos/metabolismo

\footnotetext{
'Universidade do Mato Grosso, Cuiabá, MT, Brazil.

Corresponding author: Fabiana Vieira Breijão Zani - Rua Celulta Mourão Monteiro, 170 - Centro -Zip code: 37220-000 - Bom Sucesso, MG, Brazil - Phone: (55 35) 3841-1381 -E-mail: breijao@yahoo.com.br Received on: Sep 3, 2014 - Accepted on: Apr 19, 2015

Conflict of interest: none.

DOI: 10.1590/\$1679-45082015A03251
} 


\section{INTRODUCTION}

A 6-8 hours fasting period for solids and liquids is the traditional management in the preoperative preparation process. ${ }^{(1)}$ Prospective randomized studies demonstrated that reducing the preoperative fasting to 2 hours along with ingestion of a maltodextrin solution provides emotional and especially metabolic benefits, besides not determining anesthesia-associated risk for pulmonary aspiration. ${ }^{(2,3)}$ There are many references to this concept in publications by the European group ERAS (Enhanced Recovery After Surgery), and by our research group ACERTO, (Aceleração da Recuperação Total Pós-operatória). ${ }^{(2,4)}$

The ingestion of liquids with maltodextrin, especially in medium and large surgeries, modulates the metabolic response to trauma by lowering insulin resistance, thus attenuating nitrogen (protein) consumption and consequently reducing the loss of strength and function of skeletal muscles. ${ }^{(4)}$ A positive interference with the nitrogen balance implies preservation of muscular strength and reducing postoperative complications.

Cholecystolithiasis is an endemic disease that usually requires elective surgery and may present with pulmonary complications. ${ }^{(5)}$ In the immediate postoperative period, there is often a restrictive respiratory disorder usually leading to reduced forced vital capacity (FVC), and reduced forced expiratory volume in the first second $\left(\mathrm{FEV}_{1}\right)$. These changes typically indicate the occurrence of restrictions in lung function. ${ }^{(6)}$

There are few data in literature about the influence of a short-time preoperative fast with maltodextrin solution on muscle strength and lung function.

\section{OBJECTIVE}

To evaluate pulmonary function and functional capacity in the immediate preoperative period and 24 hours after surgery in patients undergoing elective cholecystectomy by laparotomy, with either prolonged or shortened fasting.

\section{METHODS}

This was a prospective randomized clinical trial including 92 patients treated at the Surgical Outpatients Clinic of Hospital Santa Helena, in Cuiabá (MT), Brazil, from January to December 2011. The study was approved by the Research Ethics Committee of the Hospital Universitário Júlio Müller, Universidade Federal de Mato Grosso, protocol number 783/CEP-HUJM/10. All participants signed an Informed Consent Form.
The inclusion criteria were female patients with an indication for cholecystectomy by laparotomy and spinal anesthesia, aged 18 to 60 years, with body mass index (BMI) ranging from 18.5 to $29.5 \mathrm{~kg} / \mathrm{m}^{2}$, American Society of Anesthesiology (ASA) I and II, and Subjective Global Assessment (SGA) A. We excluded patients requiring cholecystectomy with bile duct exploration, patients who underwent surgery with operative time longer than 120 minutes or whose anesthesia had to be converted to general anesthesia, patients requiring another immediate surgical procedure, patients with postoperative complications, pregnant patients, and those suffering from diabetes, hypertension, chronic obstructive pulmonary disease, lung disease, heart disease, arthritis, and gastroesophageal reflux disease.

The groups were differentiated based on preoperative fasting period. G1 was composed of patients who underwent shortened fasting, with restriction of solids for 8 hours and ingestion of tea with addition of $12.5 \%$ maltodextrin in $400 \mathrm{~mL}$ and $200 \mathrm{~mL}, 6$ and 2 hours, respectively, before the scheduled time for surgical procedure. In G2, the patients followed the prolonged fasting time, with no intake of solids or liquids for a period of at least 8 hours before the operation.

The surgical procedure was performed by the same professional team and with the same standard surgical technique. Spinal anesthesia was used and all patients were sedated with intravenous midazolam at a dose of 0.01 to $0.08 \mathrm{mg} / \mathrm{kg}$.

Analgesia was initiated in the recovery room, consisting of $2 \mathrm{~g}$ of dipyrone and $75 \mathrm{mg}$ of sodium diclofenac. Subsequently, dypirone $1 \mathrm{~g}$ was prescribed every 6 hours. Prophylactic antibiotic therapy with cefazolin was prescribed.

Data collection was carried out in two stages: in the preoperative period, 2 hours before surgery; and 24 hours after starting time of surgery.

The spirometry variables measured were $\mathrm{PEF}, \mathrm{FEV}_{1}$ e FVC. The incentive spirometer One Flow FVC ${ }^{\circledR} \mathrm{HS}$ Clement Clarke International (Harlow, Essex, England) unit, with a disposable nozzle as interface between patient and spirometer, was used for all measurements.

The patients remained seated, with their heads in neutral position, without bending the neck and using a nose clip. Maximal inspiration was made until they reached their inspiratory capacity, followed by a blow as fast and as hard as possible reaching the vital capacity. Three reproducible maneuvers were done with a 1 minute interval between them. The best value curve, as elected by the spirometer software, was included for data analysis. 
The variables for muscle strength were dominant hand grip strength (dHGS) and non-dominant handgrip strength (ndHGS), measured by a hydraulic dynamometer (Saehan Corporation, Masan, Korea).

Measurement was performed with the patient seated on a chair with a straight back and no support for the arms, shoulder adducted and neutrally rotated, elbow flexion at $90^{\circ}$, forearm and wrist in neutral position between zero and $30^{\circ}$ of extension, and zero and $15^{\circ}$ of ulnar deviation. Three measurements were performed, and the arithmetic mean of the two highest readings of each hand was used for analysis. ${ }^{(7)}$

Randomization was performed by the GraphPad software website (http://www.graphpad.com/quickcalcs/ index.cfm). All variables were normally distributed after applying the Kolmogorov-Smirnov test, thus justifying the use of parametric statistical methods. Individual variables, clinical characteristics, spirometry and functional capacity values were compared according to the preoperative fasting and postoperative evaluation, initially by Student's $t$ test for independent variables. Later, the Student's $t$ test was used with dependent groups (paired) for intragroup comparison (pre-and postoperatively). The arithmetic means and standard deviation results were used for all analyses, as displayed on the tables. The level of significance was set at $5 \%$, using the Epi-Info, version 3.5.2, and Statistical Package for the Social Science (SPSS), version 13.0, for Windows software.

\section{RESULTS}

One hundred and six patients were considered for randomization, in that, 53 patients for each group. Fourteen patients were eliminated by the exclusion criteria (manipulation of the biliary tract, previous intraoperative cholangiography, operative time $>120$ minutes, and requirement of general anesthesia).

The final sample consisted of 92 patients, G1 was composed of 47 patients, and G2, of 45 . All patients completed the study. There were no postoperative complications, and no patient dropped out or refused compliance with the protocol. The individual characteristics of patients and operative variables are presented on table 1 .

The results showed no differences in demographic and clinical variables between the two groups. There were also no statistical differences regarding the time of surgery and size of the incision, in addition to variables related to the preoperative evaluation ( $\mathrm{PEF}, \mathrm{FEV}_{1}$, FVC, dHGS and ndHGS), problably because the good adjustment when applying the inclusion criteria.
Table 1. Clinical characteristics and variables of the surgery

\begin{tabular}{lccc}
\hline Characteristics & Mean & Standard deviation & p value \\
\hline Age (years) & & & \\
$\quad$ Shortened fasting & 40.1 & 10.9 & \\
$\quad$ Prolonged fasting & 49.8 & 11.6 & $\mathrm{~ns}$ \\
$\begin{array}{l}\text { Incision size (cm) } \\
\quad \text { Shortened fasting }\end{array}$ & 10.35 & 2.9 & \\
$\quad$ Prolonged fasting & 10.39 & 4.4 & $\mathrm{~ns}$ \\
Duration of operation (minutes) & & & \\
$\quad$ Shortened fasting & 73.4 & 19.4 & \\
$\quad$ Prolonged fasting & 77.0 & 16.8 & $\mathrm{~ns}$ \\
BMl (kg/cm2) & & & \\
$\quad$ Shortened fasting & 24.6 & 2.5 & $\mathrm{~ns}$ \\
$\quad$ Prolonged fasting & 22.8 & 3.8 & \\
\hline $\mathrm{ns}$ not significant: BMl: body massindex & & &
\end{tabular}

All study variables (PEF, $\mathrm{FEV}_{1}, \mathrm{FVC}$, dHGS and ndHGS) were similar in both groups in the preoperative evaluation. However, postoperatively these variables showed statistically significant differences, with higher values in G1 than in G2 (Table 2).

Table 2. Preoperative and postoperative spirometry values and functional capacity according to type of fasting

\begin{tabular}{|c|c|c|c|c|}
\hline \multirow[b]{2}{*}{ Variable } & \multicolumn{2}{|c|}{ Preoperative } & \multicolumn{2}{|c|}{ Postoperative } \\
\hline & Mean ( $\pm S D$ ) & $\begin{array}{c}\mathbf{p} \\
\text { value }\end{array}$ & Mean ( \pm SD) & $\begin{array}{c}\mathbf{p} \\
\text { value }\end{array}$ \\
\hline \multicolumn{5}{|c|}{ Peak expiratory flow (L/min) } \\
\hline Shortened fasting & $182.5( \pm 82.5)$ & & $128.7( \pm 62.5)$ & \\
\hline Prolonged fasting & $180.4( \pm 85.2)$ & ns & $115.7( \pm 59.9)$ & ns \\
\hline \multicolumn{5}{|c|}{$\begin{array}{l}\text { Forced expiratory volume in } \\
\text { first second }(L)\end{array}$} \\
\hline Shortened fasting & $2.1( \pm 0.7)$ & & $1.5( \pm 0.6)$ & \\
\hline Prolonged fasting & $1.9( \pm 0.7)$ & ns & $1.2( \pm 0.5)$ & 0.040 \\
\hline \multicolumn{5}{|c|}{ Forced vital capacity (L) } \\
\hline Shortened fasting & $2.9( \pm 1.1)$ & & $2.3( \pm 1.1)$ & \\
\hline Prolonged fasting & $1.9( \pm 1.1)$ & ns & $1.8( \pm 0.9)$ & 0.021 \\
\hline \multicolumn{5}{|c|}{ Dominant handgrip strength $(\mathrm{kg})$} \\
\hline Shortened fasting & $25.2( \pm 6.7)$ & & $24.9( \pm 6.8)$ & \\
\hline Prolonged fasting & $23.1( \pm 8.4)$ & ns & $18.4( \pm 7.7)$ & 0.001 \\
\hline \multicolumn{5}{|c|}{$\begin{array}{l}\text { Non-dominant handgrip } \\
\text { strength }(\mathrm{kg})\end{array}$} \\
\hline Shortened fasting & $24.8( \pm 6.4)$ & & $22.9( \pm 6.3)$ & \\
\hline Prolonged fasting & $22.4( \pm 8.5)$ & ns & $17.0( \pm 7.8)$ & 0.0002 \\
\hline
\end{tabular}

ns: not significant; SD: standard deviation.

In the intergroup analysis there was no difference in G1, except for the variable dHGS. However, in G2, all variables showed pre- and postoperative differences (Table 3). 
Table 3. Intragroup comparison of spirometry values and functional capacity in group submitted to shortened fasting with maltodextrin (G1) and in group submitted to conventional fasting (G2)

\begin{tabular}{|c|c|c|c|c|}
\hline \multirow[b]{2}{*}{ Variable } & \multicolumn{2}{|l|}{ G1 } & \multicolumn{2}{|l|}{ G2 } \\
\hline & Mean ( \pm SD) & $\begin{array}{c}\mathbf{p} \\
\text { value }\end{array}$ & Mean ( \pm SD) & $\begin{array}{c}\mathbf{p} \\
\text { value }\end{array}$ \\
\hline \multicolumn{5}{|c|}{ Peak expiratory flow (L/min) } \\
\hline Preoperative & $182.5( \pm 82.5)$ & & $180.4( \pm 85.2)$ & \\
\hline Postoperative & $128.7( \pm 62.5)$ & $<0.001$ & $115.7( \pm 59.9)$ & $<0.001$ \\
\hline \multicolumn{5}{|c|}{$\begin{array}{l}\text { Forced expiratory volume in } \\
\text { first second }(L)\end{array}$} \\
\hline Preoperative & $2.1( \pm 0.7)$ & & $1.9( \pm 0.7)$ & \\
\hline Postoperative & $1.5( \pm 0.6)$ & $<0.001$ & $1.2( \pm 0.5)$ & $<0.001$ \\
\hline \multicolumn{5}{|c|}{ Forced vital capacity (L) } \\
\hline Preoperative & $2.9( \pm 1.1)$ & & $2.7( \pm 1.1)$ & \\
\hline Postoperative & $2.3( \pm 1.1)$ & 0.001 & $1.8( \pm 0.9)$ & $<0.001$ \\
\hline \multicolumn{5}{|c|}{$\begin{array}{l}\text { Dominant handgrip } \\
\text { strength }(\mathrm{kg})\end{array}$} \\
\hline Preoperative & $25.2( \pm 6.7)$ & & $23.1( \pm 8.4)$ & \\
\hline Postoperative & $24.9( \pm 6.8)$ & ns & $18.4( \pm 7.7)$ & $<0.001$ \\
\hline \multicolumn{5}{|c|}{$\begin{array}{l}\text { Non-dominant handgrip } \\
\text { strength }(\mathrm{kg})\end{array}$} \\
\hline Preoperative & $24.8( \pm 6.4)$ & & $22.4( \pm 8.5)$ & \\
\hline Postoperative & $22.9( \pm 6.3)$ & 0.006 & $17.0( \pm 7.8)$ & $<0.001$ \\
\hline
\end{tabular}

The results of this study showed that shortened fasting with maltodextrin preserved muscle strength in the dominant hand. No patient had complications with anesthesia and there were no deaths. All patients were discharged 24 hours after surgery.

Another finding of this study was that there was loss of muscle function after surgery. Comparing the types of fasting, the best values were observed in the group with the shortened fasting.

\section{DISCUSSION}

The results of this study demonstrated that shortened fasting using maltodextrin brought benefits to lung function and preserved muscle strength in the dominant hand. Therefore, it contributed to a better clinical outcome, since reduced lung function and reduced muscle strength are associated with postoperative complications. This result is in agreement with several other studies that showed safety and benefits of shorter fasting time. ${ }^{(8-12)}$

Several studies demonstrated that a shortened fasting had favorable emotional effects on the patients, such as reducing hunger, sadness, thirst, anxiety, malaise, and irritability. ${ }^{(10)}$ In terms of metabolism, this shortened fasting also positively modulates the response to trauma, by determining a better organic response to surgical stress. ${ }^{(13)}$
In 2010 it was shown that a prolonged preoperative fasting diminishes the substrate reserves, thus affecting mitochondrial function of mononuclear cells. ${ }^{(14)}$ Additionally, this is associated with a lower muscular RNAm and reduced pyruvate dehydrogenase kinase, and the latter is the mechanism that makes the ingestion of a solution containing maltodextrin cause attenuation of the development of postoperative insulin resistance. ${ }^{(15)}$

The strengths of this study were evaluation of the respiratory and muscular functions as the endpoint variables of the two different preoperative fasting approaches. We did not find in the literature any study evaluating the effect of a shorter fasting on lung and muscular functions assessed in the same patient. This is the first study to use this approach and indicates the need of further research with this methodology.

The decreased respiratory function found in this study was similar to what reported by some authors in this same type of surgery. ${ }^{(5,16-19)}$ Gastaldi et al. ${ }^{(20)}$ showed lower values on the second postoperative day (FVC and $\mathrm{FEV}_{1}$ ). Muehling et al. ${ }^{(21)}$ observed that a shortened fasting time in lung operations led to lower pulmonary complication rates. Furthermore, they found lower $\mathrm{FEV}_{1}$ values in this group, which is similar to our results.

Our results indicated that a shortened fasting using maltodextrin was beneficial to the respiratory dynamics, probably due to maintenance of muscular strength.

Another finding of this study was that there was a loss of muscle function postoperatively. Comparing the types of fasting, the shortened fasting group had the best findings.

The preservation of dHGS in the shortened fasting group probably reflects the behavior of the skeletal muscles as a whole.

Some studies showed that low levels of HGS in the preoperative period are strong indicators of postoperative complications, ${ }^{(22,23)}$ besides predicting a worsening in functional status during hospitalization, ${ }^{(23,24)}$ with a consequent increase in mortality rate of these patients.

Klidjian et al., ${ }^{(23)}$ in a pioneer study on dynamometry and postoperative complications, observed that $95 \%$ of patients who developed complications had a HGS $85 \%$ lower than that of healthy individuals. Another study conducted in an intensive care unit revealed that the lower the HGS, the greater association with hospital mortality $(\mathrm{OR}=4.5 ; 95 \%$ CI 1.5-13.6; $\mathrm{p}=0.007) .{ }^{(25)}$

A study by Bragagnolo et al. ${ }^{(26)}$ demonstrated that thickness of the abductor muscle of the thumb and HGS index are safe methods of nutritional assessment, and that HGS of the dominant hand is a good prognostic indicator in patients who are candidate for large digestive surgeries. 
A recent study found that the prevalence of malnutrition among hospitalized patients is high. This most often occurs as the result of the fasting required for tests, diagnostic procedures, or surgeries. In these cases, HGS is a relevant prognostic method, proving that the adequate intake of food during the first week of hospitalization leads to increased grip strength bilaterally. ${ }^{(27)}$

Perrone et al. ${ }^{(28)}$ found that the intake of nutrients (carbohydrate and protein) in the immediate preoperative period is seen as a beneficial factor to minimize the organic response to surgical stress and improve welfare of patients. The supply of a fluid containing $12.5 \%$ carbohydrate and protein, 6 and 2 hours before surgery in patients undergoing colorectal surgery, decreased peripheral resistance to insulin and unpleasant manifestations, such as thirst and hunger, which resulted in enhanced wellbeing and less anxiety and stress, without causing gastric stasis.

The patients submitted to laparoscopic cholecystectomy showed a significant decrease in lung volumes and respiratory muscle strength on the first postoperative day. However, when compared with data from literature, their return to preoperative values was quicker in laparoscopic surgery than in open abdominal surgery. ${ }^{(16,18,19)}$

The supply of carbohydrates before surgery reduces the organic metabolic effects associated with surgical trauma. ${ }^{(19,29,30)}$ It can be inferred that in greater magnitude surgeries, in which the organic response is more intense, this routine can promote a lower metabolic impact and therefore, provide important benefits to the patients.

In this study, 2 hours fasting was safe in 95\% of cases due to the strict control of fluid supply in the preoperative period. However, a limitation was the fact that the participants in our study were not "blinded". Another limitation was the size of surgeries (medium size), since in such procedures there is less metabolic aggression, in addition to less postoperative complications, thus producing smaller impacts of shorttime fasting on the body. Nevertheless, strength of the study was its satisfactory sample size.

The present study adds new data to the literature on the advantages of shortened fasting, now focusing on preservation of muscle and respiratory function; it thus allows inferring that this change in the protocol may represent a positive impact on the clinical evolution of the patient.

\section{CONCLUSION}

The shorter preoperative fasting time, with supply of a fluid containing maltodextrin before elective mediumsized operations was beneficial to the lung function and preserved the dominant hand grip strength of patients.

\section{ACKNOWLEDGEMENTS}

We would like to thank the contributions from the General Surgery Residency Program of Hospital Santa Rosa, Hospital Santa Helena, and Ms. Maristela Prado for her support.

\section{REFERENCES}

1. Mendelson CL. The aspiration of stomach contents into the lungs during obstetric anesthesia. Am J Obst Gynecol.1946;52:191-205.

2. Melis GC, van Leeuwen PA, von Blomberg-van der Flier BM, Goedhart-Hiddinga AC, Uitdehaag BM, Strack van Schijndel RJ, et al. A carbohydrate-rich beverage prior to surgery prevents surgery-induced immunodepression: a randomized controlled, clínical trial. JPEN J Parenter Enteral Nutr. 2006;30(1):21-6.

3. Noblett SE, Watson DS, Huong H, Davison B, Hainsworth PJ, Horgan AF. Pre-operative oral carbohydrate loading in colorectal surgery: a randomized controlled trial. Colorectal Dis. 2006;8(7):563-9

4. Diks J, van Hoorn DE, Nijveldt RJ, Boelens PG, Hofman Z, Bouritius $H$, et al. Preoperative fasting: an outdated concept? JPEN J Parenter Enteral Nutr. 2005;29(4):298-304. Review.

5. Dronkers J, Veldman A, Hoberg E, van der Waal C, van Meeteren N. Prevention of pulmonary complications after upper abdominal surgery by preoperative intensive inspiratory muscle training: a randomized controlled pilot study. Clin Rehabil. 2008;22(2):134-42

6. Pecora DV. Predictability of effects of abdominal and thoracic surgery upon pulmonary function. Ann Surg. 1969;170(1):101-8.

7. Schlüssel MM, Anjos LA, Kac G. A dinamometria manual e seu uso na avaliação nutricional: revisão. Rev Nutr. 2008;21(2):233-5.

8. Oliveira KG, Balsan M, Oliveira Sde S, Aguilar-Nascimento JE. [Does abbreviation of preoperative fasting for two hours with carbohydrates increase the anesthetic risk?]. Rev Bras Anestesiol. 2009;59(5):577-84. Portuguese.

9. Faria MS, de Aguilar-Nascimento JE, Pimenta OS, Alvarenga LC Jr, DockNascimento DB, Slhessarenko N. Preoperative fasting of 2 hours minimizes insulin resistance and organic response to trauma after video-cholecystectomy: a randomized, controlled, clinical trial. World J Surg. 2009;33(6):1158-64.

10. Aguilar-Nascimento JE, Bicudo-Salomão A, Caporossi C, Silva RM, Cardoso EA, Santos TP. Enhancing surgical recovery in Central-West Brazil: The ACERTO protocol results. E Spen Eur E J Clin Nutr Metab. 2008;3(2):e78-e83.

11. Yuill KA, Richardson RA, Davidson HI, Garden OJ, Parks RW. The administration of an oral carbohydrate-containing fluid prior to major elective uppergastrointestinal surgery preserves skeletal muscle mass postoperatively--a randomised clínical trial. Clin Nutr. 2005;24(1):32-7.

12. Søreide E, Eriksson LI, Hirlekar G, Eriksson H, Henneberg SW, Sandin R, Raeder J; (Task Force on Scandinavian Pre-operative Fasting Guidelines, Clinical Practice Committee Scandinavian Society of Anaesthesiology and Intensive Care Medicine). Pre-operative fasting guidelines: an update. Acta Anaesthesiol Scand. 2005;49(8):1041-7. Review.

13. Caporossi C, Salomão A. ACERTO - Acelerando a recuperação total no pósoperatório. 2a ed. In: Aguilar-Nascimento J, editor. Cuiabá: Editora da UFMT; 2009. p.71.

14. Awad S, Stephenson M, Placidi E, Marciani L, Constantin-Teodosiu D, Gowland PA, et al. The effects of fasting and refeeding with a 'metabolic preconditioning' drink on substrate reserves and mononuclear cell mitochondrial function. Clin Nutr. 2010;29(4):538-44.

15. Awad S, Constantin-Teodosiu D, Constantin D, Rowlands B, Fearon K, Macdonald I, et al. Cellular mechanisms underlying the protective effects of preoperative feeding: a randomized study investigating muscle and liver glycogen content, mitochondrial function, gene and protein expression. Ann Surg. 2010;252(2):247-53. 
16. Ramos GC, Pereira E, Gabriel Neto S, Oliveira EC. Avaliação da função pulmonar após colecistectomias laparoscópicas e convencionais. Rev Col Bras Cir. 2007;34(5):326-30.

17. Chetta A, Tzani P, Marangio E, Carbognani P, Bobbio A, Olivieri D. Respiratory effects of surgery and pulmonary function testing in the preoperative evaluation. Acta Biomed. 2006;77(2):69-74. Review.

18. Chiavegato $L D$, Jardim JR, Faresin $S M$, Juliano Y. Alterações funcionais respiratórias na colecistectomia por via laparoscópica. J Pneum. 2000;26(2):69-76.

19. Dias CM, Plácido TR, Ferreira MF, Guimarães FS, Menezes SL. Inspirometria de incentivo e breath stacking: repercussões sobre a capacidade inspiratória em indivíduos submetidos à cirurgia abdominal. Rev Bras Fisiot. 2008;12(2):94-9.

20. Gastaldi AC, Magalhães CM, Baraúna MA, Silva EM, Souza HC. Benefícios da cinesioterapia respiratória no pós-operatório de colecistectomia laparoscópica. Rev Bras Fisiot. 2008;12(2):100-6.

21. Muehling BM, Halter GL, Schelzig H, Meierhenrich R, Steffen P, SunderPlassmann $L$, et al. Reduction of postoperative pulmonary complications after lung surgery using a fast track clinical pathway. Eur J Cardio-Thoracic Surg. 2008;34(1):174-80.

22. Norman K, Stobäus N, Gonzalez MC, Schulzke JD, Pirlich M. Hand grip strength: outcome predictor and marker of nutritional status. Clin Nutr. 2011;30(2):135-42.

23. Klidjian AM, Foster KJ, Kammerling RM, Cooper A, Karran SJ. Relation of anthropometric and dynamometric variables to serious postoperative complications. Br Med J. 1980;281(6245):899-901.
24. Alvares-da-Silva MR, Reverbel da Silveira T. Comparison between handgrip strength, subjective global assessment, and prognostic nutritional index in assessing malnutrition and predicting clínical outcome in cirrhotic outpatients. Nutrition. 2005;21(2):113-7.

25. Bicudo-Salomão A, Meireles MB, Caporossi C, Crotti PL, de Aguilar-Nascimento JE. Impact of the ACERTO project in the postoperative morbi-mortality in a university hospital. Rev Col Bras Cir. 2011;38(1):3-10

26. Bragagnolo R, Caporossi FS, Dock-Nascimento DB, Aguilar-Nascimento JE. [Adductor pollicis muscle thickness: a fast and reliable method for nutritional assessment in surgical patients]. Rev Col Bras Cir. 2009;36(5):371-6. Portuguese.

27. Perdomo LG. Avaliação da ingestão oral e capacidade funcional de pacientes internados no Hospital Universitário Julio Muller [dissertação]. Cuiabá: Universidade Federal de Mato Grosso; 2011.

28. Perrone F, da-Silva-Filho AC, Adorno IF, Anabuki NT, Leal FS, Colombo T, et al. Effects of preoperative feeding with a whey protein plus carbohydrate drink on the acute phase response and insulin resistance. A randomized trial. Nutr J. 2011;10:66.

29. de Aguilar-Nascimento JE, Perrone F, de Assunção Prado LI. [Preoperative fasting of 8 hours or 2 hours: what does evidence reveal?]. Rev Col Bras Cir. 2009;36(4):350-2. Review. Portuguese.

30. Gustafsson UO, Hausel J, Thorell A, Ljungqvist O, Soop M, Nygren J; Enhanced Recovery After Surgery Study Group. Adherence to the enhanced recovery after surgery protocol and outcomes after colorectal surgery. Arch Surg. 2011;146(5):571-7. 